\title{
Magnitude and factors associated with malnutrition in children 6-59 months of age in Shinille Woreda, Ethiopian Somali regional state: a cross-sectional study
}

\author{
Abdibari Ma'alin', Dereje Birhanu², Samuel Melaku ${ }^{3}$, Daniel Tolossa ${ }^{4 *}$, Yusuf Mohammed $^{5}$ and Kiros Gebremicheal ${ }^{1}$
}

\begin{abstract}
Background: Malnutrition among children remains common in many parts of the world, particularly in developing countries. In Ethiopia, it is one of the most important health and welfare problems among infants and young children. Ethiopian Somali regional state is one of the most underserved regions in terms of access to essential services and characterized by a high level of child malnutrition, food insecurity, and vulnerable livelihoods. Therefore, the current study was undertaken to assess the magnitude and factors associated with malnutrition among children aged 6-59 months in Shinille Woreda, Ethiopian Somali regional state.

Methods: Community-based cross-sectional survey, involving 694 study participants selected by multistage sampling technique, was conducted in Shinile Woreda from February to March, 2014. Data were collected using structured questionnaire and anthropometric measurement. Anthropometric indices were calculated using ENA for SMART software 2011, and SPSS V.16 was used for data analysis. Associations were computed using the OR and $95 \%$ Cl. P-value less than 0.05 were considered as statistically significant.

Results: The overall prevalence of stunting, underweight and wasting were $33.4 \%, 24.5 \%$ and $20 \%$, respectively. The main associated factors of stunting and wasting were family size, child's sex and monthly income of the households. Immunization status was the only variable associated with all forms of malnutrition. Non-immunized children were 2.5 times more likely become underweight than their counterparts. The prevalence of stunting was 3 . 8 times higher in households with large family size. Female children were 1.5 times more likely become wasted than their counterparts.

Conclusion: Prevalence of malnutrition among under five children in Shinile Woreda is still high. Our finding highlighted the importance of childhood vaccination, family planning and poverty alleviation as potential targets for intervention.
\end{abstract}

Keywords: Malnutrition, Shinille Woreda, Ethiopia

\footnotetext{
* Correspondence: danieltolossa@yahoo.com

${ }^{4}$ Department of Medical Laboratory Technology, Jig-jiga Health Science

College, Jig-jiga, Ethiopia

Full list of author information is available at the end of the article
} 


\section{Background}

Malnutrition among children remains common in many parts of the world [1]. It is the underlying cause of death in an estimated $45 \%$ of all deaths among children under 5 years of age [2]. The prevalence of worldwide stunting, underweight and wasting in children under 5 years of age were $24.7 \%, 15.1 \%$ and $7.8 \%$, respectively [3]. Malnutrition is particularly prevalent in developing countries [4]. For example, in Africa, chronic malnutrition affected about $39.9 \%$ of children in the same age group [3]. In South-East Asia, the prevalence rate of underweight was estimated to be at around $26.6 \%$ [3].

The effects of malnutrition on human performance, health and survival have been the subject of extensive research for several decades $[5,6]$. In the long term, early nutritional deficits are linked to impairments of intellectual performance; work capacity, reproductive outcomes and overall health during adolescence and adulthood [6-11]. The immediate consequences of poor nutrition during the early formative years include significant morbidity and mortality and delayed mental and motor developments [11]. Malnutrition at the early stages of life can lower child resistance to infections [12]. Moreover, the potential negative impact of child malnutrition goes beyond the individual, affecting society and future generations [13, 14].

Several factors which are associated with malnutrition have been identified, including poor breastfeeding and child feeding practices [15-18], lack of access to enough nutritious food [19], low levels of parental education [20-22] and belonging to the low-income group [23$25]$. In addition, lack of access to health services $[19,22]$ and poor follow up of antenatal services [15] were also recognized as a key determinant of child malnutrition. Furthermore, nutritional status is clearly compromised by diseases [26], such as HIV-infection [27], parasitic infection (e.g. giardia) [28], diarrhea and other illness (including fever, cough, common cold, pneumonia, ear infection, and/or skin diseases) $[16,22,29,30]$.

In Ethiopia, child malnutrition rate is one of the most serious public health and welfare problems for many years (Fig. 1) [31-33]. Currently, Ethiopia is responding to an El Niño-caused drought emergency that has driven food insecurity, malnutrition and water shortages in affected areas of the country. Sitti Zone of the Ethiopian Somali Regional State (ESRS) is one of the highly impacted areas with more than 400,000 people exposed to shortage of food and water. The drought has also resulted in loss of livestock and hence livelihoods that are already vulnerable have been stretched further. To mitigate the problem of child malnutrition, micro level studies on its cause and status of prevalence are needed. Therefore, this study was conducted in Shinile Woreda, the largest of seven Woredas in Sitti Zone, to assess the status of malnutrition and its associated risk factors among children aged 6 to 59 months.

\section{Methods \\ Study area}

The current study was conducted in Shinile Woreda, ESRS, between February and March, 2014. The ESRS is one of the nine regional states that constitute the federal democratic republic of Ethiopia [34]. Geographically, the region occupies a large area and falls in the eastern and southeastern part of the country with land mass area of about $350,000 \mathrm{~km}^{2}$ and an estimated total population of $4,445,219$ people [34]. $86.1 \%$ of the population resides in rural areas while only $13.9 \%$ reside in urban areas [34]. Shinille Woreda has a latitude and longitude of $09^{\circ}$ $41^{\prime} \mathrm{N}$ and $41^{\circ} 51^{\prime} \mathrm{E}$ with an elevation of $1079 \mathrm{~m}$ above sea level. Based on figures published by the Central Statistical Agency, the Woreda has an estimated total

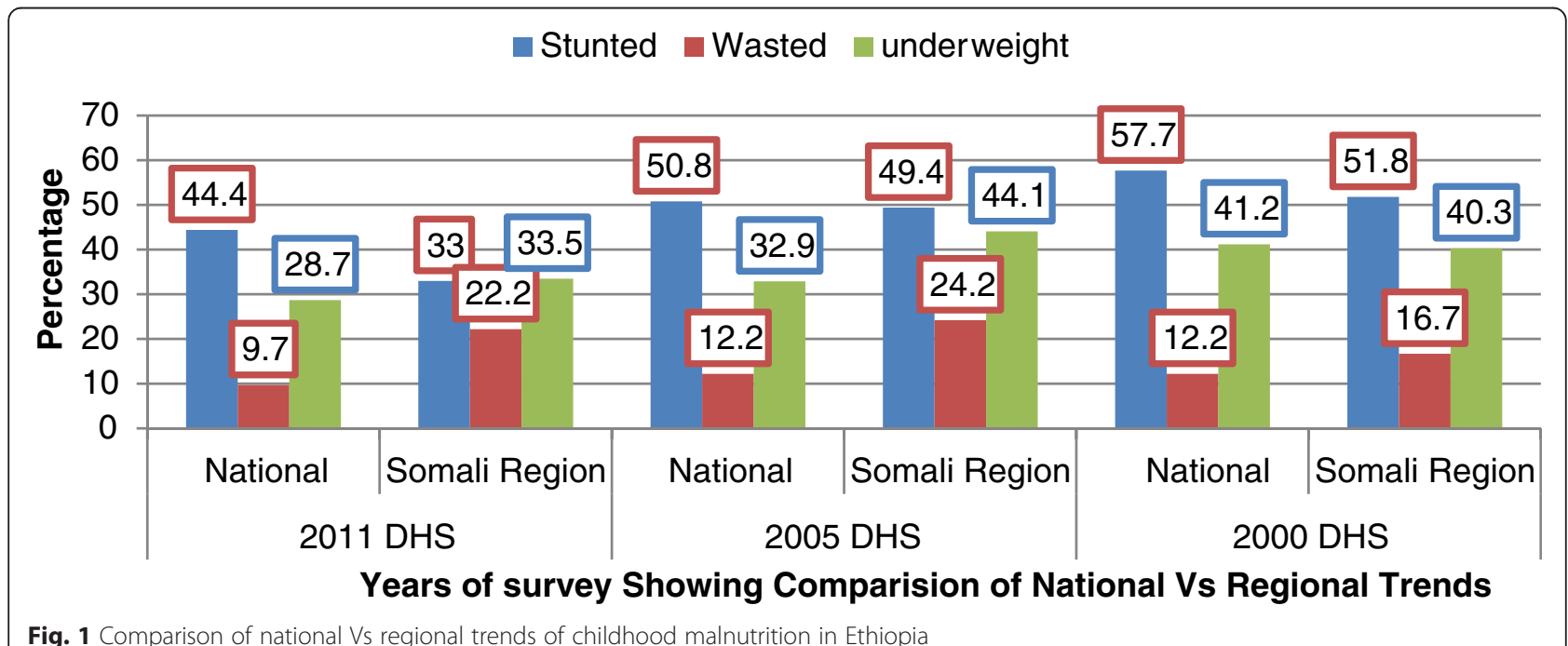

Fig. 1 Comparison of national Vs regional trends of childhood malnutrition in Ethiopia 
Table 1 Household and mothers'/care takers' characteristics in Shinille Woreda, Somali region, Ethiopia February-March, 2014 $(n=694)$

\begin{tabular}{|c|c|c|}
\hline Variable & Frequency & Percent \\
\hline \multicolumn{3}{|l|}{ Household characteristics } \\
\hline \multicolumn{3}{|l|}{ Head of the household: } \\
\hline Male & 654 & 94.2 \\
\hline Female & 40 & 5.8 \\
\hline \multicolumn{3}{|l|}{ Family size: } \\
\hline$\leq 5$ & 196 & 28.2 \\
\hline$>5$ & 498 & 71.8 \\
\hline \multicolumn{3}{|c|}{ Educational level of mother: } \\
\hline Illiterate & 503 & 72.5 \\
\hline Literate & 191 & 27.5 \\
\hline \multicolumn{3}{|c|}{ Educational level of father: } \\
\hline Illiterate & 236 & 34 \\
\hline Literate & 458 & 66 \\
\hline \multicolumn{3}{|l|}{ Occupation of mother: } \\
\hline House wife only & 375 & 54 \\
\hline Merchant/Trade & 139 & 20 \\
\hline Private Organization & 20 & 2.9 \\
\hline Government & 37 & 5.3 \\
\hline Daily laborer & 75 & 10.8 \\
\hline Other (specify) & 48 & 6.9 \\
\hline \multicolumn{3}{|l|}{ Ethnicity: } \\
\hline Somali & 651 & 93.8 \\
\hline Others & 43 & 6.2 \\
\hline \multicolumn{3}{|l|}{ Religion: } \\
\hline Muslim & 689 & 99.3 \\
\hline Others & 5 & 0.7 \\
\hline \multicolumn{3}{|l|}{ Monthly income: } \\
\hline$\leq 750$ & 546 & 78.7 \\
\hline$>750$ & 148 & 21.3 \\
\hline \multicolumn{3}{|c|}{ Mothers'/care takers' characteristics } \\
\hline \multicolumn{3}{|l|}{ children ever born: } \\
\hline$\leq 3$ & 186 & 26.8 \\
\hline $4-5$ & 329 & 47.4 \\
\hline$\geq 6$ & 179 & 25.8 \\
\hline \multicolumn{3}{|c|}{ Know about family planning: } \\
\hline Yes & 57 & 8.2 \\
\hline No & 637 & 91.8 \\
\hline \multicolumn{3}{|l|}{ Place of delivery: } \\
\hline Home & 557 & 80.3 \\
\hline Health institution & 137 & 19.7 \\
\hline \multicolumn{3}{|l|}{ ANC visit: } \\
\hline Yes & 150 & 21.6 \\
\hline
\end{tabular}

Table 1 Household and mothers'/care takers' characteristics in Shinille Woreda, Somali region, Ethiopia February-March, 2014 $(n=694)$ (Continued)

\begin{tabular}{lcc}
\hline No & 544 & 78.4 \\
Extra food During pregnancy: & & \\
Yes & 148 & 21.3 \\
No & 546 & 78.7 \\
\hline
\end{tabular}

population of 113,630, of which $46.6 \%$ are men and $53.4 \%$ are women; $23.91 \%$ of its population is urban dwellers, and the Woreda is composed of 30 kebeles. In this Woreda, $80 \%$ of the inhabitants are pure pastoralists, while $15 \%$ agro pastoralists and $5 \%$ of the community engaged in petty trading and other activities in urban town. The Woreda is characterized by arid and semi arid climate with an annual rain fall ranges between 450 to $550 \mathrm{~mm} /$ year. The annual temperature is varying from 30 to $37^{\circ}$ centigrade.

\section{Study design, source population and study participants}

A community-based cross-sectional study design was used. The source population was all children under five years of age residing in three kebeles, which were selected by simple random sampling. Study participants were all children 6-59 months of age who were selected by simple random sampling from eligible children in the selected households. Children were not included if they were guests, if they were seriously ill for sickness and if their mothers did not consent to participate in the survey.

\section{Sample size and sampling technique}

The required sample size was calculated using the formula required for determination of sample size for estimating single proportion. Based on the prevalence of malnutrition among under five children (29\%) [31], and with additional assumption of $95 \%$ confidence interval, $5 \%$ margin of error, a design effect of 2 due to multistage sampling and $10 \%$ non-respondent rate in our estimate, a total sample of 697 were needed. During sampling, 3 out of the 30 kebeles in the woreda were selected using simple random sampling technique and the calculated sample was proportionally distributed to the selected kebeles based on their number of households. Then, from each of the selected kebeles, households were selected using systematic random sampling technique. Finally, from all the eligible children in a household, only one was selected by simple random sampling for the anthropometric measurement. In addition, the mothers of all selected children were interviewed. But in the absence of eligible child in a given household, a substitution was made by a child in the next household. 
Table 2 Child and environmental health characteristics in Shinille Woreda, Somali region, Ethiopia February-March, 2014 $(n=694)$

\begin{tabular}{|c|c|c|}
\hline Variable & Frequency & Percen \\
\hline \multicolumn{3}{|l|}{ Child characteristics } \\
\hline \multicolumn{3}{|l|}{ Child's sex: } \\
\hline Male & 364 & 52.4 \\
\hline Female & 330 & 47.6 \\
\hline \multicolumn{3}{|l|}{ Child's age in months: } \\
\hline $6-11$ & 331 & 47.7 \\
\hline $12-23$ & 171 & 24.6 \\
\hline $24-35$ & 90 & 13 \\
\hline$\geq 36$ & 102 & 14.7 \\
\hline \multicolumn{3}{|l|}{ Child weighed at birth: } \\
\hline Yes & 137 & 19.7 \\
\hline No & 557 & 80.3 \\
\hline \multicolumn{3}{|l|}{ Immunization: } \\
\hline Yes & 175 & 25.2 \\
\hline No & 519 & 74.8 \\
\hline \multicolumn{3}{|l|}{ Diarrhea in the last two weeks } \\
\hline Yes & 132 & 19 \\
\hline No & 562 & 81 \\
\hline \multicolumn{3}{|l|}{ Respiratory disease } \\
\hline Yes & 205 & 29.5 \\
\hline No & 489 & 70.5 \\
\hline \multicolumn{3}{|l|}{ Child caring practice } \\
\hline \multicolumn{3}{|l|}{ Initiation of breast feeding: } \\
\hline Immediately & 225 & 32.4 \\
\hline After $1 \mathrm{~h}$ after birth & 469 & 67.6 \\
\hline \multicolumn{3}{|l|}{ Pre-lacteal feeding: } \\
\hline Yes & 435 & 62.7 \\
\hline No & 259 & 37.3 \\
\hline \multicolumn{3}{|l|}{ Total duration of breast feeding: } \\
\hline$<12$ & 593 & 85.4 \\
\hline$\geq 12$ & 101 & 14.6 \\
\hline \multicolumn{3}{|c|}{ Environmental Health characteristics } \\
\hline \multicolumn{3}{|l|}{ Source of drinking water: } \\
\hline Pond/River & 62 & 8.9 \\
\hline Well/Tap & 632 & 91.1 \\
\hline \multicolumn{3}{|l|}{ Availability latrine } \\
\hline Yes & 512 & 73.8 \\
\hline No & 182 & 26.2 \\
\hline \multicolumn{3}{|l|}{ Type of latrine } \\
\hline Private pit/wooden slab & 351 & 68.6 \\
\hline Private slab/cement slab & 138 & 27 \\
\hline Shared latrine/woodenslab & 23 & 4.5 \\
\hline
\end{tabular}

Table 2 Child and environmental health characteristics in Shinille Woreda, Somali region, Ethiopia February-March, 2014 $(n=694)$ (Continued)

\begin{tabular}{lll}
\hline Separate room for Kitchen & & \\
Yes & 468 & 67.4 \\
No & 226 & 32.6 \\
\hline
\end{tabular}

\section{Data collection and quality control}

Data were collected using structured questionnaire and anthropometric measurement (Additional file 1). Twelve data collectors and two supervisors were recruited from health centers and health posts in the woreda. Training was provided for data collectors and supervisor for two days.

The questionnaire was used to collect quantitative data on variables pertaining to the socioeconomic and demographic characteristics of the participants. It was first designed in English based on information from other literatures developed for similar purpose [25, 31]. After adopting to the local context, the questionnaire was translated to Somali (the local language of the study area) (Additional file 2). Moreover, the questionnaire was pre-tested on randomly selected individuals from the survey area and these individuals were not participated in the main study. During the pre-test, the questionnaire was assessed for its clarity/understandability, reliability, sensitivity of the subject matter and for cultural acceptability in the area.

The mothers/care takers of the children were interviewed to provide answers to questions other than child anthropometry. Each face to face interview was made by a house-to-house visit and the participants were interviewed in their local language. All the interviews, measurements and testing were conducted at the residences of the study participants. On daily basis, collected information was reviewed and possible errors were returned to the collectors for correction.

To assess the physical growth and nutritional status of the children, measurements of height and weight were taken of all of the children and these measurements were taken during the home visit. These anthropometric data were collected using the procedure stipulated by the WHO [35] for taking anthropometric measurements. Before taking anthropometric data for the children, their age was determined in order to ensure the target population. Local events were used to establish the birth period. The mothers were asked whether the child was born before or after certain major events until a fairly accurate age is pinpointed. If age couldn't be determined accurately, a height of $65-110 \mathrm{~cm}$ was considered as proxy indicators.

Body length of children aged up to 23 months were measured without shoes and the height was read to the 


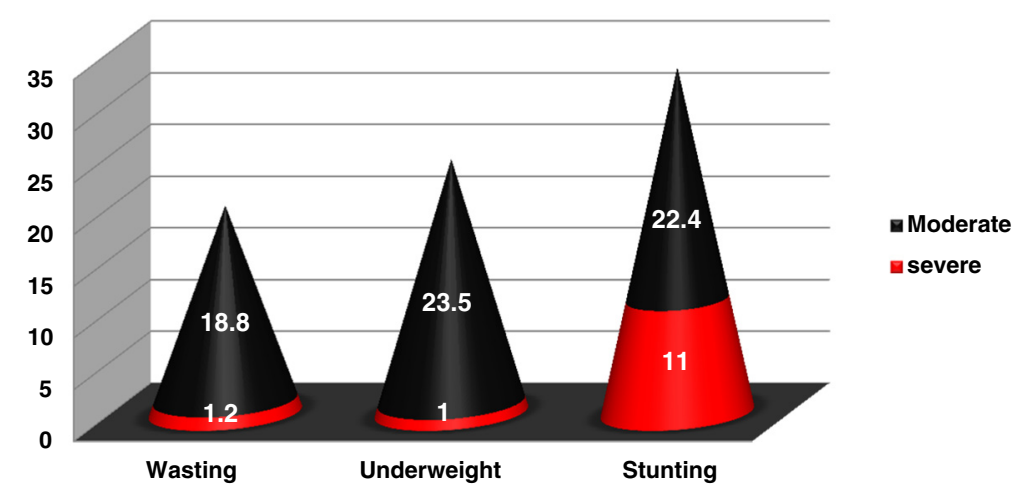

Fig. 2 Overall prevalence of malnutrition among 6-59 months old children in Shinille Wereda, Somali region, February, $2014(n=694)$

nearest $0.1 \mathrm{~cm}$ by using a horizontal wooden length board with the infant in recumbent position. However, height of children aged 24 months and above was measured using a vertical wooden height board by placing the child on the measuring board, and child standing upright in the middle of board. The child's head, shoulders, buttocks, knees and heels touching the board.

Weight was measured by electronic digital weight scale (salter model 235-6 s) with lightly clothing and no shoes. Calibration was done before weighing every child by setting it to zero. In case of children aged below two years, the scale was allowed weighing of very young children through an automatic mother-child adjustment that were eliminated the mother's weight while she standing on the scale with her baby.

Edema was checked and noted on data sheet because children with edema were severely malnourished. In order to determine the presence of edema, normal thumb pressure was applied to the two feet for three seconds whether a shallow print or pint remains on both feet when the thumb is lifted.

To identify retrospective morbidity of children, mothers were asked about any occurrence of illness during the past two weeks. Enumerators probe to confirm nature of illness based on operational case definition and was asked to identify occurrence of measles in the past one year. In addition, vaccination status of children was checked by observing immunization card and if not available mothers were asked to recall it. BCG vaccination was checked by observing scar on right (also left) arm.

\section{Variables of the study}

The main outcome variables were: prevalence of stunting, wasting and underweight as determined by anthropometric measurements of weight and height taking age and sex into consideration. Five categories of independent variables were included in the data analysis. 1) Socio-economic and demographic variables; such as head of the family (father or mother), family size, income, ethnicity, religion, parental literacy (able to read or write) and occupation. 2) Child characteristics; Age, Sex, birth order, place of delivery, types of birth, birth size/weight, breastfeeding status, gestational age and morbidly status (fever, measles, diarrhea). 3) Child caring practices; feeding, hygiene, health care seeking and immunization. 4) Maternal characteristics; age, number of children ever born, antenatal care (ANC) visits, health status during pregnancy, use of extra food during pregnancy/lactation and autonomy in decision-making on use of money. 5) Environmental health condition; Water supply, sanitation and housing conditions.

\section{Data processing and analysis}

First, the data were checked manually for completeness and consistency. Then, it was coded and entered in the computer using EPI-INFO3.5.1 software and then sex, age, height and weight transferred to ENA for SMART 2007 software to convert nutritional data into Z-scores of the indices; Height-for-Age Z-scores (HAZ), Weightfor-Height Z-scores (WHZ) and Weight-for-Age Zscores (WAZ) using the National Center for Health Statistics reference population standard of WHO. A child was considered stunted, wasted or underweight if the corresponding HAZ, WHZ and WAZ -scores were less than -2 . When the measures of HAZ, WHZ and WAZ were less than -3 , the child was considered severely stunted, severely wasted and severely underweight, respectively. Then, the data were exported to SPSS V.16 for analysis. Descriptive summary using frequencies, proportions, graphs and cross tabs were used to present study results. Bivariate analysis was computed to determine the association of malnutrition and associated factors. Statistical association was checked by $95 \%$ confidence interval (CI) and crude odd ratio (OR) and the significant variables $(p$-value $<0.25)$ observed in bivariate analysis were subsequently included in multivariate analysis. Finally, results were reported as statistically 
Table 3 Bivariate and Logistic regression analyses showing the impact of selected variables On malnutrition as measured by stunting, Shinille woreda, Ethiopia Somali region, February, $2014(n=694)$

\begin{tabular}{|c|c|c|c|c|c|}
\hline \multirow[t]{2}{*}{ Variables } & \multicolumn{5}{|c|}{ Stunting } \\
\hline & Yes & No & $\mathrm{OR}(\mathrm{Cl})$ & $\mathrm{AOR}(\mathrm{Cl})$ & $P$ \\
\hline \multicolumn{6}{|l|}{ Family size } \\
\hline$\leq 5$ & 36 & 160 & 1 & 1 & \\
\hline$>5$ & 196 & 302 & $2.88(1.92,4.31)$ & $3.82(2.20,6.60)$ & 0.01 \\
\hline \multicolumn{6}{|l|}{ Edu. level of mother } \\
\hline Illiterate & 191 & 312 & $0.44(0.30,0.65)$ & $4.95(2.87,8.52)$ & 0.01 \\
\hline Literate & 41 & 150 & 1 & 1 & \\
\hline \multicolumn{6}{|l|}{ Occup of mother } \\
\hline House wife only & 112 & 263 & 1 & 1 & \\
\hline Merchant/Trade & 54 & 85 & $1.49(0.99,2.24)$ & $0.81(0.46,1.44)$ & 0.48 \\
\hline Priv. Organization & 10 & 10 & $2.34(0.95,5.79)$ & $0.93(0.24,3.49)$ & 0.91 \\
\hline Gove. employee & 17 & 20 & $1.99(1.00,3.95)$ & $1.74(0.60,5.01)$ & 0.30 \\
\hline Daily laborer & 18 & 57 & $0.74(0.41,1.31)$ & $0.55(0.22,1.36)$ & 0.20 \\
\hline Other (specify) & 21 & 27 & $1.82(0.99,3.36)$ & $2.49(1.05,5.89)$ & 0.03 \\
\hline \multicolumn{6}{|l|}{ Monthly income } \\
\hline$\leq 750$ & 210 & 336 & $3.58(2.20,5.18)$ & $3.48(1.99,6.06)$ & 0.01 \\
\hline$>750$ & 22 & 126 & 1 & 1 & \\
\hline \multicolumn{6}{|c|}{ Extra food During preg. } \\
\hline Yes & 48 & 100 & 1 & 1 & \\
\hline No & 184 & 362 & $1.05(0.71,1.56)$ & $0.90(0.41,1.95)$ & 0.79 \\
\hline \multicolumn{6}{|l|}{ Health during preg. } \\
\hline Good & 116 & 227 & 1 & 1 & \\
\hline Not good/sick & 116 & 235 & $0.96(0.70,1.32)$ & $1.42(0.89,2.29)$ & 0.14 \\
\hline \multicolumn{6}{|c|}{ Visited H. facility for ANC } \\
\hline Yes & 58 & 92 & 1 & 1 & \\
\hline No & 174 & 370 & $0.76(0.51,1.08)$ & $0.49(0.30,0.80)$ & 0.004 \\
\hline \multicolumn{6}{|l|}{ Child's sex } \\
\hline Male & 91 & 273 & 1 & 1 & \\
\hline Female & 141 & 189 & $2.23(1.62,3.089)$ & $2.54(1.69,3.83)$ & 0.01 \\
\hline \multicolumn{6}{|l|}{ Child's age } \\
\hline $6-11$ & 113 & 218 & 1 & 1 & \\
\hline $12-23$ & 72 & 99 & $1.40(0.96,2.05)$ & $0.79(0.45,1.36)$ & 0.40 \\
\hline $24-35$ & 35 & 55 & $1.22(0.75,1.98)$ & $1.55(0.79,3.02)$ & 0.19 \\
\hline$\geq 36$ & 12 & 90 & $0.25(0.13,0.49)$ & $0.15(0.07,0.31)$ & 0.13 \\
\hline \multicolumn{6}{|l|}{ Immunization } \\
\hline Yes & 23 & 152 & 1 & 1 & \\
\hline No & 209 & 310 & $4.45(2.77,7.14)$ & $9.20(5.03,16.84)$ & 0.01 \\
\hline \multicolumn{6}{|l|}{ Initiation of CF } \\
\hline$\leq 6$ & 202 & 388 & 1 & 1 & \\
\hline$>6$ & 30 & 74 & $0.77(0.49,1.23)$ & $1.44(0.70,2.93)$ & 0.31 \\
\hline \multicolumn{6}{|c|}{ Total duration of breast feeding } \\
\hline$<12$ & 222 & 371 & $5.44(2.77,10.68)$ & $0.12(0.05,0.27)$ & 0.01 \\
\hline$>12$ & 10 & 91 & 1 & 1 & \\
\hline
\end{tabular}


Table 3 Bivariate and Logistic regression analyses showing the impact of selected variables On malnutrition as measured by stunting, Shinille woreda, Ethiopia Somali region, February, $2014(n=694)$ (Continued)

\begin{tabular}{|c|c|c|c|c|c|}
\hline \multicolumn{6}{|c|}{ Source of drinking water } \\
\hline Pond/River & 21 & 41 & 1 & & \\
\hline Well/Tap & 211 & 421 & $0.97(0.56,1.69)$ & $0.57(0.26,1.23)$ & 0.15 \\
\hline \multicolumn{6}{|c|}{ Availability latrine } \\
\hline Yes & 178 & 334 & 1 & 1 & \\
\hline No & 54 & 128 & $0.79(0.54,1.14)$ & $1.92(1.14,3.22)$ & 0.01 \\
\hline
\end{tabular}

significant whenever $p$-values were less than 0.05 at $95 \%$ CI. OR was used to report strength of association between background variables and the target outcome variables.

\section{Results}

Socio demographic characteristic

In this study, the final analysis included 694 motherchild pairs for which a complete data were obtained making the response rate $100 \%$. Most (94.2\%) of the households were male headed, $71.8 \%$ had more than five family members, $93 \%$ belongs to the Somali ethnic group and almost all (99\%) were Muslims (Table 1). The prevalence of illiterate parents was higher (72.5\%) for mothers than fathers (34\%). Majority (54\%) of the mothers were house wife, $47.4 \%$ gave birth of four to five children, $82 \%$ did not ever used family planning, $80.3 \%$ delivered at home and $78 \%$ did not attend ANC. Regarding consumption of extra food during pregnancy and/or lactation of the index child, only $21.3 \%$ of mother reported consumption of extra food than when they were not pregnant or lactating. Only about onethird of the mothers initiated breastfeeding practice immediately after birth but $67.6 \%$ started within an hour after birth (Table 2). More than $62 \%$ of the mothers reported giving pre-lacteal feed to their newborn and $85.4 \%$ continued breast feeding their children for about less than 12 months. Of the 694 children aged 6-59 months, $52.4 \%$ were boys, $47.7 \%$ were in the age range of 6-11 months and only $19.7 \%$ were weighed at birth. Regarding vaccination and illness status of the children, only $25.2 \%$ were immunized, and $19 \%$ and $29.5 \%$ had diarrhea and respiratory disease respectively in the previous two weeks before the survey. Majority (91.1\%) of the households used well/tap as a source of water, about $73.8 \%$ of the households had latrine, of which two third $(68.6 \%)$ were privately owned pit latrine. $67.4 \%$ of Households had separate room for kitchen.

\section{Stunting}

The prevalence of stunting among children of the study areas was $33.4 \%$, of which $11 \%$ of children were severely stunted (Fig. 2). In the bivariate analysis family size, child sex, maternal education, maternal occupation, monthly income, extra feeding during pregnancy/lactation, health status of mother during pregnancy, ANC visit, child sex, initiation of breast feeding, immunization status, continuation of breast feeding, source of drinking water and availability of latrine have significant association to stunting. However, the final multivariate analysis showed that vaccination status, maternal literacy, child sex, family size and monthly income were the significant risk factors of childhood malnutrition as measured by stunting (Table 3). The prevalence of stunting was 9.2 times higher in children who did not receive any vaccine than those who received vaccine $(\mathrm{AOR}=9.20$, with $95 \%$ CI: 5.03 to 16.84), 4.9 times higher in children of illiterate mothers than their counterparts $(\mathrm{AOR}=4.95$, 95 \% CI: 2.87 to 8.52), 2.5 times higher in children who were female than those who were male $(\mathrm{AOR}=2.54$, with $95 \%$ CI: 1.69 to 3.83), 3.8 times higher in households with large family size than those households with small family size (AOR $=3.82,95 \% \mathrm{CI}: 2.20$ to 6.60 ) and 3.5 times higher in households having monthly income of less than 750 birr than those households having monthly income of greater than 750 birr $(\mathrm{AOR}=3.48$, $95 \% \mathrm{CI}: 1.99$ to 6.06$)$.

\section{Wasting}

The result of Fig. 2 reveals that $20 \%$ of the children were wasted, of which $18.8 \%$ of children were moderately malnourished. Results from bivariate analysis showed that family size, immunization status, maternal education, monthly income, extra feeding during pregnancy/lactation, ANC visit, continuation of breast feeding, birth order, how long after birth did you first put the child to breast feed and availability of latrine have significant association to wasting. However, the final multivariate analysis shows that family size $(\mathrm{AOR}=2.01$; $95 \% \mathrm{CI}=1.13$ to 3.57 ), monthly income of the household $(\mathrm{AOR}=1.78 ; 95 \% \mathrm{CI}: 1.03$ to 3.04$)$, sex of child $(\mathrm{AOR}=1.50 ; 95 \% \mathrm{CI}=1.00$ to 2.26$)$ and immunization status $(\mathrm{AOR}=7.57 ; 95 \% \mathrm{CI}=3.65$ to 15.70 ) were the significant risk factors of childhood malnutrition as measured by wasting (Table 4). Children from large family size were 2.0 times more likely to be wasted than 
Table 4 Bivariate and Logistic regression analyses showing the impact of selected variables on malnutrition as measured by wasting Shinille woreda, Ethiopia Somali region, February, 2014 (n 694)

\begin{tabular}{|c|c|c|c|c|}
\hline \multirow[t]{2}{*}{ Variables } & \multicolumn{4}{|l|}{ Wasting } \\
\hline & Yes No & $\mathrm{OR}(\mathrm{Cl})$ & $\mathrm{AOR}(\mathrm{Cl})$ & P \\
\hline
\end{tabular}

Family size

$\begin{array}{lllll}\leq 5 & 22 & 174 & 1 & 1\end{array}$

$\begin{array}{lllllll}>5 & 117 & 381 & 2.42(1.48,3.963) & 2.01 & (1.13,3.57) & 0.01\end{array}$

Edu. level of mother

$\begin{array}{cccclcc}\text { Illiterate } & 107 & 396 & 1.34(0.86,2.07) & 1.43(0.91,2.24) & 0.11 \\ \text { Literat } & 32 & 159 & 1 & 1 & \\ \text { Monthly income } & & & & & \\ \leq 750 & 120 & 426 & 1.91(1.13,3.22) & 1.78(1.03,3.04) & 0.03 \\ \geq 750 & 19 & 129 & 1 & 1 & \end{array}$

Extra food During preg.

$\begin{array}{lllll}\text { Yes } & 22 & 126 & 1 & 1\end{array}$

No $\quad 117 \quad 429 \quad 1.56(0.95,2.56) \quad 0.90(0.41,1.95) \quad 0.79$

Visited $\mathrm{H}$. facility for ANC

$\begin{array}{llllll}\text { Yes } & 25 & 125 & 1 & 1 & \\ \text { No } & 114 & 430 & 1.32(0.82,2.13) & 1.07(0.82,1.96) & 0.82\end{array}$

Place of delivery

$\begin{array}{llllll}\text { Home } & 112 & 445 & 1 & 1 & \\ \text { Health institution } & 27 & 110 & 0.97(0.61,1.55) & 1.48(0.83,2.62) & 0.17\end{array}$

Child's sex

$\begin{array}{llllll}\text { Male } & 64 & 300 & 1 & 1 & \\ \text { Female } & 75 & 255 & 1.37(0.94,2.00) & 1.50(1.00,2.26) & 0.05 \\ \begin{array}{c}\text { Child's age } \\ 6-11\end{array} & 65 & 266 & 1 & 1 & \\ 12-23 & 36 & 135 & 1.09(0.69,1.72) & 0.64(0.39,1.07) & 0.09 \\ 24-35 & 22 & 68 & 1.32(0.76,2.29) & 1.15(0.62,2.12) & 0.64 \\ \geq 36 & 16 & 86 & 0.76(0.41,1.38) & 0.70(0.37,1.31) & 0.26 \\ \text { Immunization } & & & & & \\ \text { Yes } & 9 & 166 & 1 & 1 & \\ \text { No } & 130 & 389 & 6.16(3.06,12.40) & 7.57(3.65,15.70) & 0.01\end{array}$

How long after birth did you first put the child to breast feed

$\begin{array}{llllll}\text { Immediately } & 35 & 190 & 0.64(0.42,0.98) & 0.77(0.48,1.22) & 0.27 \\ \text { After } 1 \text { h of birth } & 104 & 365 & 1 & 1 & \\ \text { Total duration of breast feeding } & 123 & 470 & 1.39(0.78,2.45) & 1.36(0.74,2.50) & 0.31 \\ <12 & 16 & 85 & 1 & 1\end{array}$

Birth order between the current baby and his elder

\begin{tabular}{llllll}
$<2$ years & 26 & 163 & 1 & 1 & \\
$3-4$ years & 52 & 166 & $0.59(0.35,0.97)$ & $1.38(0.63,3.04)$ & 0.41 \\
$>=5$ years & 61 & 226 & $1.16(0.76,1.76)$ & $1.42(0.67,3.04)$ & 0.35 \\
\hline
\end{tabular}

children from small family size, children from households having monthly income of less than 750 birr were 1.8 times more likely to be wasted than children from households having monthly income of less than 750 birr, non-immunized children were 7.6 times more likely to be wasted than their counter parts and female were 1.5 times more wasted than boys.

\section{Underweight}

The prevalence of underweight among the under five children was $24.5 \%$. Around $23.5 \%$ of children were moderately malnourished. Variables like family size, maternal occupation, extra feeding during pregnancy/lactation, health status of mother during pregnancy, birth order, immunization status, initiation of complementary feeding, continuation of breast feeding, source of drinking water and availability of latrine were variables significantly associated to underweight using binary logistic regression model. From all tested variables, only immunization status $(\mathrm{AOR}=2.47 ; 95 \% \mathrm{CI}=1.374$ to 4.439) and total duration of breast feeding ( $\mathrm{AOR}=2.16$; $95 \% \mathrm{CI}=1.11$ to 4.20 ) were significantly associated with malnutrition as measured by underweight in final multivariate analysis (Table 5). Accordingly, non-immunized children were 2.5 times more likely become underweight than their counterparts and children who breast feed less than 12 months were 2.2 times more likely become underweight than those who feed more than 12 months.

\section{Discussion}

The findings of this study indicate that $33.4 \%, 25.5 \%$ and $20 \%$ of the sample children were stunted, underweight and wasted, respectively, which is similar to previous studies done in the northwest part of Ethiopia [24, 36], in Jimma zone, south west of the country [37], and in Shinile zone, ESRS [38]. However, in accordance with the EDHS report [31] and earlier studies in Afar region [39] and northern part of Ethiopia [40] as well as in India [15], Bangladesh [16, 25] and Uganda [27], the prevalence of stunting and underweight in the current study is low. On the other hand, the prevalence of wasting is high compared to the national report [31] and other similar studies [23, 24, 36, 38, 41, 42]. The differences in the prevalence of malnutrition among children could be attributed to the difference in the method of data collection, sample size, study subjects or may be due to socioeconomic and seasonal variation as compared with the present study.

The regression analysis of this study indicated immunization status of children as an important risk factor for all the three categories of malnutrition (stunting, wasting and underweight). Similarly, undernourished children from rural Bangladesh [16] and Northwest Ethiopia were less likely to have received 
Table 5 Bivariate and Logistic regression analyses showing the impact of selected variables on malnutrition as measured by underweight, Shinille woreda, Ethiopia Somali region, February, $2014(n=694)$

\begin{tabular}{|c|c|c|c|c|c|}
\hline \multirow[t]{2}{*}{ Variables } & \multicolumn{5}{|c|}{ Underweight } \\
\hline & Yes & No & $\mathrm{OR}(\mathrm{Cl})$ & $\mathrm{AOR}(\mathrm{Cl})$ & $P$ \\
\hline \multicolumn{6}{|l|}{ Family size } \\
\hline$\leq 5$ & 32 & 164 & 1 & 1 & \\
\hline$>5$ & 138 & 360 & $1.96(1.28,3.01)$ & $1.37(0.65,2.88)$ & 0.40 \\
\hline \multicolumn{6}{|c|}{ Children $<5$ years in the households } \\
\hline$<2$ & 147 & 477 & 1 & 1 & \\
\hline$>=2$ & 23 & 47 & $1.58(0.93,2.70)$ & $0.81(0.36,1.77)$ & 0.60 \\
\hline \multicolumn{6}{|l|}{ Occupat of mother } \\
\hline House wife only & 90 & 285 & 1 & 1 & \\
\hline Merchant/Trade & 38 & 101 & $1.19(0.76,1.85)$ & $1.79(0.95,3.37)$ & 0.06 \\
\hline Priv. Organization & 5 & 15 & $1.05(0.37,2.98)$ & $3.14(0.94,10.54)$ & 0.06 \\
\hline Gove. employee & 20 & 17 & $3.72(1.87,7.41)$ & $2.13(0.69,6.59)$ & 0.18 \\
\hline Daily laborer & 6 & 69 & $0.27(0.11,0.65)$ & $0.90(0.33,2.45)$ & 0.83 \\
\hline Other (specify) & 11 & 37 & $0.94(0.46,1.92)$ & $1.36(0.54,3.39)$ & 0.50 \\
\hline \multicolumn{6}{|c|}{ Extra food During preg. } \\
\hline Yes & 28 & 120 & 1 & 1 & \\
\hline No & 142 & 404 & $1.50(0.95,2.37)$ & $1.77(0.98,3.19)$ & 0.05 \\
\hline \multicolumn{6}{|l|}{ Health during preg. } \\
\hline Good & 76 & 267 & 1 & 1 & \\
\hline Not good/sick & 94 & 257 & $1.28(0.90,1.81)$ & $1.11(0.70,1.77)$ & 0.63 \\
\hline \multicolumn{6}{|l|}{ Place of delivery } \\
\hline Home & 125 & 432 & 1 & 1 & \\
\hline Health institution & 45 & 92 & $1.69(1.12,2.54)$ & $1.19(0.58,2.47)$ & 0.62 \\
\hline \multicolumn{6}{|l|}{ Birth order } \\
\hline$<2$ years & 39 & 150 & 1 & 1 & \\
\hline $3-4$ years & 71 & 147 & $1.85(1.18,2.91)$ & $1.41(0.76,2.62)$ & 0.26 \\
\hline$>=5$ years & 60 & 227 & $1.01(0.64,1.59)$ & $0.65(0.35,1.20)$ & 0.17 \\
\hline \multicolumn{6}{|l|}{ Immunization } \\
\hline Yes & 31 & 144 & 1 & 1 & \\
\hline No & 139 & 380 & $1.69(1.10,2.62)$ & $2.47(1.37,4.43)$ & 0.01 \\
\hline \multicolumn{6}{|l|}{ Initiation of CF } \\
\hline$\leq 6$ & 153 & 437 & 1 & 1 & \\
\hline$>6$ & 17 & 87 & $0.55(0.32,0.96)$ & $0.72(0.33,1.53)$ & 0.39 \\
\hline \multicolumn{6}{|c|}{ Total duration of breast feeding } \\
\hline$\leq 12$ & 158 & 435 & $2.69(1.43,5.05)$ & $2.16(1.11,4.20)$ & 0.02 \\
\hline$>12-24$ & 12 & 89 & 1 & 1 & \\
\hline \multicolumn{6}{|l|}{ Availability latrine } \\
\hline Yes & 137 & 375 & 1 & 1 & \\
\hline No & 33 & 149 & $0.60(0.39,0.927)$ & $1.18(0.66,2.14)$ & 0.56 \\
\hline
\end{tabular}

vaccination [43]. Non-immunized children are more likely to be frequently infected with vaccine preventable diseases such as diarrhea and respiratory infections, which are known in depleting nutrients from the body.
The current study also revealed that family size and child sex become associated with stunting and wasting. With this regards, children living in a family of five or more were more stunted than their counterparts. The 
finding corroborates previous studies in Sudan [44], Pakistan [45], Ethiopia [43] and elsewhere [46]. Logically, as family size increases, the chance of becoming malnourished also increase probably due to other factors that may contribute to nutritional status, such as income of the family become less when there is increased family size. Female children were having higher risk of being stunted and wasted as compared to male children, which agrees with previous studies in Bangladesh [16], india [15, 47], Iran [48] and as well as Ethiopia [47]. On the contrary, malnutrition was significantly higher among boys than among girls in Botswana [4], Karaikal District of India [49] and Ecuador [22] and as well as in Ethiopia, the national data reported that male children were slightly more likely to be stunted and wasted than female children [31]. In the current study area, the care for children is closely linked with cultural and gender issues where in the region family are usually fevering to males than female children.

It was also found out that the prevalence of stunting and wasting had a significant relationship to family income. Chronic malnutrition and acute malnutrition were 3.5 times and 1.78 times, respectively, higher among children from households having monthly income of less than 750 birr than those from households having monthly income of greater than 750 birr. This is in accordance with previous studies conducted in Serbia [21], India [15], and as well as in Ethiopia [23-25, 31, 38, 46] and elsewhere [45]. Families with enough monthly income can access enough nutritious foods and as well as health care and educational facilities.

Mother's education has been identified in other populations as a predictor of childhood malnutrition [19, 20, $25,31,44,48,50]$. We also found mother's education to be a predictor of stunting. Ahmed et al. [16] also reported that undernourished children were more likely to have illiterate/less educated mother. Similarly, Indian children of the mothers who studied up to higher secondary and graduation were less malnourished [15]. Educated mothers are more aware about the kinds and the amounts of food appropriate for their children.

The risk of having poor nutrition condition was found significantly higher for the children with poor feeding practices compared to those having better feeding practices [50]. For instance, in agreement with our study, breastfeeding was found to reduce the occurrence of underweight among children [4]. The Odds of underweight among children's of mothers not breast feeding was 2 times higher when compared with children of mothers still beast feeding during the survey [37]. Therefore, there is need to educate mothers on the protective effect of breast milk and safe breastfeeding practices as well.

\section{Limitations}

A number of limitations can be identified that might have affected our findings. As the study is crosssectional in design, it neither represents seasonal variation of nutritional outcomes particularly to the wasting status nor establishes causal relationship. Dietary aspect which is the immediate determinant of nutritional status is not included in this study. Some measurements may not be accurate due to subjective responses and recall biases from answers based on the memories of the mothers. Excluding sick children would have excluded those with malnutrition, who are more likely to be sick.

\section{Conclusion}

Prevalence of malnutrition among under five children in Shinile Woreda is still high. Factors contributing to malnutrition were diverse; including immunization status of the child, family size, child's sex, monthly income of the household, maternal education and total duration of breast feeding. Our finding highlighted the importance of childhood vaccination, family planning, poverty alleviation and extensive nutrition education programmes as potential targets for intervention.

\section{Additional files}

Additional file 1: Questionnaire for the study of the magnitude and factors associated with malnutrition in children 6-59 months of age in Shinille Woreda, ESRS, February to March, 2014.doc, 28.0 kb. (DOCX 26 kb)

Additional file 2: Somali version of the questionnaire for the study of the magnitude and factors associated with malnutrition in children 6-59 months of age in Shinille Woreda, ESRS, February to March, 2014.doc, $28.0 \mathrm{~kb}$. (DOCX $26 \mathrm{~kb})$

\section{Abbreviations}

ANC, Antenatal care; BCG, Bacillus Calmate Guerin; Cl, Confidence Interval; ESRS, Ethiopian Somali Regional State; HAZ, Height-for-Age Z-scores; OR, Odds ratio; WAZ, Weight-for-Age Z-scores; WHZ, Weight-for-Height Z-scores.

\section{Acknowledgements}

We would like to thank the ESRS and Bahir Dar University, College of Agriculture and Environmental Sciences Graduate Program for Technical supports. We would also like to forward our gratitude to all data collectors, facilitator and study participants involved in this study.

\section{Funding}

This study received financial support from the Ethiopian Somali regional state.

\section{Availability of data and materials}

All the data supporting our findings is contained within the manuscript and additional files.

\section{Authors' contributions}

AM: conception of the research idea, study design, coordination of data collection, data entry and analysis, interpretation of the data and drafting the manuscript; DB, SM: proposal revision and approval, study design, data entry and analysis, interpretation of the data and review of the manuscript; DT, YM, KG: data analysis, interpretation of data and review of the manuscript. All authors have read and approved of the final version of the manuscript. 


\section{Competing interests}

The authors declare that they have no competing interests.

\section{Consent for publication}

Not applicable.

\section{Ethics approval and consent to participate}

Ethical clearance was obtained from the Ethical Clearance Committee of the Institute of Disaster Risk Management and Sustainable Development Studies, Bahir Dar University. Permission to precede the study was obtained from the ESRS and from administrative bodies of the woreda including kebeles. Moreover, the study questionnaires were anonymous and interviews were conducted in a private setting to maintain privacy of the respondents. Objectives of the study were explained for the respondents prior to the administration of the interview and verbal consent was obtained from each respondent after confidentiality and voluntary participation features of the study were explained.

\section{Author details}

'Department of Public Health, Jig-jiga Health Science College, Jig-jiga, Ethiopia. ${ }^{2}$ School of Public Health, College of Medicine and Health Science, Bahir Dar University, Bahir Dar, Ethiopia. ${ }^{3}$ Department of Clinical Nursing, Jig-jiga Health Science College, Jig-jiga, Ethiopia. ${ }^{4}$ Department of Medical Laboratory Technology, Jig-jiga Health Science College, Jig-jiga, Ethiopia. ${ }^{5}$ Public Health Emergency Management, Ethiopian Somali Regional Health Bureau, Jig-jiga, Ethiopia.

\section{Received: 17 November 2015 Accepted: 18 June 2016} Published online: 15 July 2016

\section{References}

1. World Health Organization. World health statistics. Geneva: WHO report; 2011.

2. Black RE, Victora CG, Walker SP, Bhutta ZA, Christian P, de Onis M, et al. Maternal and child undernutrition and overweight in low-income and middle-income countries. Lancet. 2013;382(9890):427-51. http://www. thelancet.com/pdfs/journals/lancet/PIIS0140-6736(13)60937-X.pdf.

3. World Health Organization. World health statistics. Geneva: WHO report; 2014.

4. Mahgoub EO, Nnyepi M, Bandeke T. Factors affecting prevalence of malnutrition among children under three years of age in Botswana. Afr J Food Agric Nutr Dev. 2006;6:1.

5. International Food Policy Research Institute. Actions and Accountability to Advance Nutrition and Sustainable Development. Washington, DC: Global Nutrition Report 2015. http://ebrary.ifpri.org/utils/getfile/collection/ p15738coll2/id/129443/filename/129654.pdf.

6. de Onis M, Dewey GK, Borghi E, Onyango WA, Blössner M, Daelmans B. The World Health Organization's global target for reducing childhood stunting by 2025: rationale and proposed actions. John Wiley \& Sons Ltd Matern Child Nutr. 2013:9:6-26.

7. Gillespie S, Haddad L, Mannar V, Menon P, Nisbett N, The Maternal and Child Nutrition Study Group. The politics of reducing malnutrition: building commitment and accelerating progress. Lancet. 2013;382:552-69. http:// www.thelancet.com/pdfs/journals/lancet/PIIS0140-6736(13)60842-9.pdf

8. Bhutta AZ, Das KJ, Rizvi A, Gaffey FM, Walker N, Horton S, et al. Evidencebased interventions for improvement of maternal and child nutrition: what can be done and at what cost? Lancet. 2013;382:452-77. http://www. thelancet.com/pdfs/journals/lancet/PIIS0140-6736(13)60996-4.pdf.

9. United Nations Children's Fund. Progress for children: a world fit for children statistical review. New York: UNICEF; 2007.

10. Nita B, Sarmila M, Rajiv B, Jose M, Robert B, Maharaj K. Educational intervention to promote appropriate complementary feeding practices and physical growth in infants and young children in rural Haryana. J Nutr. 2004; 134:2342-8.

11. Central Statistical Agency, ORC Macro. Ethiopian demographic and health survey (EDHS) 2005. Addis Ababa, Ethiopia and Calverton, Maryland: Central Statistical Agency and ORC Macro; 2006.

12. Leonor R, Elsa C, Rocio O. Malnutrition and gastrointestinal and respiratory infections in children: a public health problem. Int J Environ Res Public Health. 2011;8:1174-205.

13. Victora CG, Adair L, Fall C, Hallal PC, Martorell R, Richter L, et al. Maternal and child undernutrition: consequences for adult health and human capital. Lancet. 2008:371:340-57.
14. Grantham-McGregor S, Cheung YB, Cueto S, Glewwe P, Richter L, Strupp B. Developmental potential in the first 5 years for children in developing countries. Lancet. 2007;369(9555):60.

15. Stalin P, Bazroy J, Dimri D, Singh Z, Senthilvel V, Sathyanarayanan S. Prevalence of underweight and its risk factors among under five children in a rural area of Kancheepuram District in Tamil Nadu, India. IOSR J Dent Med Sci. 2013;3(6):71-4. http://iosrjournals.org/iosr-jdms/papers/Nol3-issue6/ P0367174.pdf.

16. Ahmed AM, Ahmed T, Roy SK, Alam N, Hossain I. Determinants of under nutrition in children under 2 years of age from rural Bangladesh. Indian pediatrics. 2012. http://www.indianpediatrics.net/oct2012/821.pdf.

17. Muhimbula SH, Issa-Zacharia A. Persistent child malnutrition in Tanzania: risks associated with traditional complementary foods (a review). Afr J Food Sci. 2010;4(11):679-92. http://www.academicjournals.org/journal/AJFS/articlefull-text-pdf/3001DDC26158.

18. Anderson KA, Bignell W, Winful S, Soyiri J, Steiner-Asiedu M. Risk factors for malnutrition among children 5-years and younger in the Akuapim-North District in the Eastern Region of Ghana. Curr Res J Biol Sci. 2010;2(3):183-8.

19. Lang'o BD. Social determinants of child under-nutrition in urban informal settlements in Kenya. NICK Project research partnership 2011. [African Institute for Health \& Development Pathways to Better Nutrition Series: No. 1]

20. Rayhan I, Khan HS. Factors causing malnutrition among under five children in Bangladesh. Pak J Nutr. 2006;5(6):558-62.

21. Janevic T, Petrovic O, Bjelic I, Kubera A. Risk factors for childhood malnutrition in Roma settlements in Serbia. BMC Public Health. 2010;10:509. http://www.biomedcentral.com/1471-2458/10/509.

22. Wijaya MS. Determinants of chronic malnutrition among Ecuadorian children aged 0-23 months in Cuenca and Nabon Cantons: Faculty of Bioscience Gent. 2011. http://lib.ugent.be/fulltxt/RUG01/001/789/862/ RUG01-001789862_2012_0001_AC.pdf.

23. Reji P, Belay G, Erko B, Legesse M, Belay M. Intestinal parasitic infections and malnutrition amongst first-cycle primary schoolchildren in Adama, Ethiopia. Afr J Prm Health Care Fam Med. 2011;3:1. doi:10.4102/phcfm.v3i1.198. http:// www.phcfm.org.

24. Idris M. Assessment of nutritional status of preschool children of Gumbrit, North West Ethiopia. Ethiop J Health Dev. 2007;21(2):125-9.

25. Eticha K. Prevalence and determinants of child malnutrition in Gimbi district, Oromia region, Ethiopia, Comparative Cross - Sectional study: A thesis submitted to the graduate studies of Addis Ababa University in partial fulfillment of the requirements of the degree of Masters of Public Health. Addis Ababa University, faculty of medicine, department of community health 2007.

26. Blössner $M$, de Onis M. Malnutrition: quantifying the health impact at national and local levels. Geneva: WHO; 2005. http://apps.who.int/iris/ bitstream/10665/43120/1/9241591870.pdf.

27. Arinaitwe E, Gasasira A, Verret W, Homsy J, Wanzira H, Kakuru A, et al. The association between malnutrition and the incidence of malaria among young HIV-infected and un-infected Ugandan children: a prospective study. Malar J. 2012;11:90. http://www.malariajournal.com/content/11/1/90.

28. Sackey EM. Intestinal parasitic infections: Prevalence, risk factors and consequences for child growth, iron status and development in rural Equador. Blacksburg, VA. 2001. https://theses.lib.vt.edu/theses/available/etd-08232001195222/unrestricted/finaletd.pdf.

29. Hasanain FG, Jamsiah M, Zaleha MI, Azmi MT, Mohammed AA. Association between drinking water sources and diarrhea with malnutrition among Kindergarten's children in Baghdad city, Iraq. Malays J Public Health Med. 2012;12(1):45-8

30. Njuguna J, Muruka C. Diarrhoea and malnutrition among children in a Kenyan district: a correlational study. J Rural and Trop Public Health. 2011; 10:35-8.

31. Central Statistical Agency, ICF International. Ethiopian demographic and health survey 2011. Addis Ababa, Ethiopia and Calverton, Maryland: Central Statistical Agency and ICF International; 2012.

32. Alemu M, Nicola J, Belele T. Tackling child malnutrition in Ethiopia. Ethiopian Development Research Institute and save the children UK. 2005.

33. Central Statistical Authority. Nutrition of Young Children and Mothers in Ethiopia: Africa nutrition chartbooks. ORC Macro 11785 Beltsville Drive Calverton, Maryland, USA 2001.

34. Central Statistics Agency. The 2005 population and housing census of Ethiopia. Addis Ababa, Ethiopia and Calverton, Maryland: Central Statistical Agency and ORC Macro. 2007. 
35. de Onis M, Onyango AW, Borghi E, Siyam A, Nishida C, Siekman J. Development of a WHO growth reference for school-aged children and adolescents. Bull World Health Organ. 2007;85:660-7.

36. Amare B, Moges B, Fantahun B, Tafess K, Woldeyohannes D, Yismaw D, et al. Micronutrient levels and nutritional status of school children living in Northwest Ethiopia. Nutr J. 2012;11:108. http://www.nutritionj.com/content/ 11/1/108.

37. Beyene T. Predictors of nutritional status of children visiting health facilities in Jimma Zone, South West Ethiopia. Int J Adv Nurs Sci Pract. 2012;1(1):1-13. http://medical.cloud-journals.com/index.php/IJANSP/article/ view/Med-09/pdf

38. Mayer AM. The causes of malnutrition in children under 3 in the Somali Region of Ethiopia related to household caring practices: Preliminary Report. Save the Children (UK). 2007. http://www.alnap.org/resource/3591.

39. Fentaw R, Bogale A, Abebaw D. Prevalence of child malnutrition in agropastoral households in Afar Regional State of Ethiopia. Nutr Res Pract. 2013; 7(2):122-31. http://synapse.koreamed.org/Synapse/Data/PDFData/0161NRP/ nrp-7-122.pdf

40. Mulugeta A, Hagos F, Kruseman G, Linderhof V, Stoecker B, Abraha Z, et al. Child malnutrition in Tigray, Northern Ethiopia. East Afr Med J 2010;87(6):248-54.

41. Amare B, Ali J, Moges B, Yismaw G, Belyhun Y, Gebrestadik S, et al. Nutritional status, intestinal parasite infection and allergy among school children in Northwest Ethiopia. BMC Pediatr. 2013;13:7. http://www. biomedcentral.com/1471-2431/13/7.

42. Nguyen NL, Gelaye B, Aboset N, Kumie A, Williams MA, Berhane Y. Intestinal parasitic infection and nutritional status among school children in Angolela, Ethiopia. J Prev Med Hyg. 2012;53:157-64.

43. Mekonnen H, Tadesse T, Kisi T. Malnutrition and its Correlates among Rural Primary School Children of Fogera District, Northwest Ethiopia. J Nutr Disorders Ther. 2013; S12:002. doi:10.4172/2161-0509.S12-002.

44. Nabag OF, Elfaki EA, Ahmed KO. Socio - economic and environmental risk factors of protein energy malnutrition among children under five years of age in Omdurman pediatric hospital. Merit Research Journal of Food Science and Technology 2013;1(1):001-8. http://www.sustech.edu/staff_ publications/20130513101034404.pdf.

45. Jamro B, Junejo AA, Lal S, Bouk RG, Jamro S. Risk factors for severe acute malnutrition in children under the Age of five year in Sukkur. Pak J Med Res. 2012;51:4.

46. Amsalu S, Tigabu Z. Risk factors for severe acute malnutrition in children under the age of five: a case-control study. Ethiop J Health Dev. 2008;22(1):21-5.

47. Bhoite R, lyer U. Magnitude of malnutrition and iron deficiency anemia among rural school children: an appraisal. Asian J Exp Biol SCl. 2011;2(2):354-61.

48. Sharifzadeh $\mathrm{G}$, Mehrjoofard $\mathrm{H}$, Raghebi S. Prevalence of malnutrition in under 6-year olds in South Khorasan, Iran. Iran J Pediatr. 2010;20(4):435-41. http://www.ncbi.nlm.nih.gov/pmc/articles/PMC3446098/pdf/IJPD-20-435.pdf.

49. William FR, Bijou J, Ali M, Velan V. Nutritional assessment of children in the 3-5 years of Age group in Karaikal District, Pudhucherry. Nat J Res Com Med. 2012;1:2.

50. Das S, Rahman RM. Application of ordinal logistic regression analysis in determining risk factors of child malnutrition in Bangladesh. Nutr J. 2011;10: 124. http://www.nutritionj.com/content/10/1/124.

\section{Submit your next manuscript to BioMed Central and we will help you at every step:}

- We accept pre-submission inquiries

- Our selector tool helps you to find the most relevant journal

- We provide round the clock customer support

- Convenient online submission

- Thorough peer review

- Inclusion in PubMed and all major indexing services

- Maximum visibility for your research

Submit your manuscript at www.biomedcentral.com/submit 